\title{
Sub-minimal Inhibitory Concentrations of Cefmetazole Enhance Serum Bactericidal Activity In Vitro by Amplifying Poly-C9 Deposition
}

\author{
Jo Ellen Schweinle and Miyako Nishiyasu \\ Section of Infectious Disease, Department of Internal Medicine, Yale University School of Medicine, New Haven, Connecticut 06510
}

\begin{abstract}
Serum-resistant organisms grown in sub-minimal inhibitory concentrations (subMICs) of antibiotics in vitro may be rendered sensitive to complement-mediated, serum bactericidal activity. We measured ${ }^{125} \mathrm{I}-\mathrm{C} 3$ and ${ }^{125} \mathrm{I}-\mathrm{C} 9$ deposition on genetically serum resistant Salmonella montevideo SH5770 (SH5770) that was rendered serum sensitive by growth in subMICs of cefmetazole (CMZ), a parenteral, second generation, cephamycin-group antibiotic. Three times as much C3 and over six times as much C9 bound to SH5770 grown in one-fourth the MIC of CMZ compared to broth-grown bacteria. SDS-PAGE analysis and autoradiography showed that neither the ratio of C3b:iC3b ( 1:2.5) nor the nature of the C3-bacterial bond was changed by growing the organisms in CMZ. Large amounts of complement membrane attack complexes containing poly-C9 were seen only on CMZ-grown SH5770 by SDS-PAGE and autoradiography. Poly-C9 was also detected only on CMZgrown bacteria by indirect immunofluorescence and ELISA using a murine monoclonal antibody directed against a neoantigen of poly-C9. Bacterial hydrophobicity increased after growth in $\mathrm{CMZ}$, and transmission electron micrographs of CMZ-grown SH5770 showed cell wall disruption and blebbing. These results indicate that growth in subMICs of CMZ increases bacterial hydrophobic domains available for interacting with the membrane attack complex, C5b-9, allowing formation and stable insertion of bactericidal complexes containing poly-C9. (J. Clin. Invest. 1992. 89:1198-1207.) Key words: complement - C3, membrane attack complex $~ \beta$-lactam antibiotics
\end{abstract}

\section{Introduction}

Patients with infections frequently improve and may be cured by serum concentrations of antibiotics below bactericidal and even below inhibitory levels (1). One potential explanation was found when in vitro studies showed that serum-resistant, gram negative organisms grown in subinhibitory concentrations of certain antibiotics became susceptible to complement-mediated serum bactericidal activity (2-5). Generally it was felt that growth under these conditions disrupted the bacterial cell walls (2-6), providing serum factors access to vulnerable sites. Nonetheless, proof for this contention has been lacking.

C9 is the terminal complement component credited with dealing the lethal "hit" to serum-susceptible bacteria. Bacteri-

Address correspondence to Jo Ellen Schweinle, M.D., P.O. Box 3333, Department of Internal Medicine, Yale University School of Medicine, New Haven, CT 06510.

Received for publication 27 February 1991 and in revised form 10 October 1991 .

J. Clin. Invest.

(c) The American Society for Clinical Investigation, Inc.

0021-9738/92/04/1198/10 \$2.00

Volume 89, April 1992, 1198-1207 cidal C9 must bind to a vulnerable spot in the cell wall, usually in the form of multimeric $C 9(7-12)$. The ultimate location of C9 is presumably influenced by the $C 3$ binding site (13). In addition, bound $\mathrm{C} 3$ must be in the form of $\mathrm{C} 3 \mathrm{~b}$, not $\mathrm{iC} 3 \mathrm{~b}$, for complement activation to proceed to $\mathrm{C} 9$. We examined $\mathrm{C} 9$ and C3 bound to bacteria exposed to cefmetazole (CMZ), ${ }^{1}$ a new cephalosporin.

We used a genetically serum-resistant strain of Salmonella montevideo (SH5770) that has been extensively studied and thoroughly characterized (14-17). $S$. montevideo is relatively sensitive to CMZ, a parenterally administered, second generation cephamycin-group antibiotic that is microbicidal for gram negative (18), gram positive (19) and anaerobic (20) microorganisms. Subinhibitory concentrations of $\mathrm{CMZ}$ rendered SH5770 susceptible to serum killing by permitting stable deposition of polymerized $\mathrm{C} 9$ on the bacterial outer membrane.

\section{Methods}

Chemicals and buffers. HBSS, (Yale University School of Medicine Media Room) and $\mathrm{HBSS}$ containing $0.15 \mathrm{mM} \mathrm{CaCl}$ and $1 \mathrm{mM} \mathrm{MgCl}$ (HBSS ++) were used to dilute serum and to wash bacterial suspensions. Cefmetazole was a gift from the Upjohn Company (Kalamazoo, MI). Xylene was purchased from J. T. Baker (Phillipsburg, NJ). Methylamine and all other chemicals were from Sigma Chemical Co. (St. Louis, MO).

Bacteria. Salmonella montevideo (SH5770) was obtained from P. Helena Makela (Helsinki, Finland). SH5770 activates the alternative complement pathway $(15,16)$, and is phagocytosed by macrophages if opsonized by complement (16). This strain is resistant to complementmediated serum bactericidal activity in the absence of specific antibodies (17 and Fig. 1) or mannose-binding protein (17). For each experiment, unless otherwise indicated, organisms were grown overnight in tryptic soy broth, (TSB; BBL Microbiology System, Becton Dickenson and Co. Cockeysville, MD), containing various sub-minimal inhibitory concentrations (subMICs) of CMZ. The next morning the organisms were diluted 1:10 in the same concentrations of CMZ, grown to the mid-logarithmic phase, then incubated with various sera.

For experiments, concentrations of SH5770 were adjusted spectrophotometrically to yield the desired number of colony-forming units per milliliter whether or not the bacteria were grown in CMZ. Although CMZ produced elongated organisms with increased surface areas, colony-forming units per milliliter were approximately equal to those grown without $\mathrm{CMZ}$ when adjusted to the same optical density at $600 \mathrm{~nm}$.

Determination of MICs. Broth dilution MICs were determined by modification of a previously described method (21). The organisms were grown overnight with aeration in TSB, then adjusted to $1 \times 10^{6}$ CFU/ml by dilution with TSB. $1 \mathrm{ml}$ of bacteria and $1 \mathrm{ml}$ of serially diluted CMZ was added to $8 \mathrm{ml} \mathrm{TSB}$ (final bacterial concentration was $1 \times 10^{5} / \mathrm{ml}$, final CMZ concentration ranged from $25 \mathrm{mg} / \mathrm{ml}$ to 0.195

1. Abbreviations used in this paper: ADS, adsorbed serum; CMZ, cefmetazole; DOC, sodium deoxycholate; HIS, heat-inactivated serum; LB agar, Luria-Bertani agar; SubMICS, sub-minimal inhibitory concentrations; TSB, tryptic soy broth. 
$\mu \mathrm{g} / \mathrm{ml}$ ) then incubated at $37^{\circ} \mathrm{C}$ for $18 \mathrm{~h}$. At that time, the lowest concentration of antibiotic inhibiting visual bacterial growth was regarded as the MIC. An aliquot of each CMZ dilution was cultured overnight on Luria-Bertani agar (LB agar, Yale Media Room) to document bacterial viability. The MIC for CMZ was $1.56 \mu \mathrm{g} / \mathrm{ml}$.

Sera. Aliquots of normal human serum were collected from healthy, normal donors. Naturally occurring antibodies were removed from adsorbed serum (ADS) by adsorbing with glutaraldehyde-fixed bacteria, as described previously (17). Serum was also adsorbed with a mixture containing equal numbers of glutaraldehyde-fixed CMZgrown and broth-grown SH5770 (CMZ-ADS). Negative control sera heat-inactivated serum (HIS) in each case was ADS or CMZ-ADS heated to $56^{\circ} \mathrm{C}$ for $30 \mathrm{~min}$ to inactivate all complement activity.

Preparation and iodination of purified complement components. Functionally active human $\mathrm{C} 3$ and $\mathrm{C} 9$ were prepared by the procedures of Hammer et al. (22) with minor modifications. In the final step, C9 was purified to homogeneity by high performance liquid chromatography on a Pharmacia LKB (Piscataway, NJ) HPLC system using an HT hydroxylapatite column (Bio-Rad Lab, Richmond, CA) eluting with an 80 to $400 \mathrm{mM}$ phosphate gradient buffer containing $10 \mu \mathrm{M} \mathrm{CaCl}_{2}$, pH 7.7.

C3 was radiolabeled with ${ }^{125} \mathrm{I}-\mathrm{Na}$ (Dupont New England Nuclear, Boston, MA) using Iodobeads (Pierce Chemical Co., Rockford, IL) to $3.9 \times 10^{5} \mathrm{cpm} / \mu \mathrm{g}$ to $1.9 \times 10^{6} \mathrm{cpm} / \mu \mathrm{g}$. $\mathrm{C} 9$ was labeled in the same fashion to $1.6 \times 10^{5} \mathrm{cpm} / \mu \mathrm{g}$ to $6.5 \times 10^{7} \mathrm{cpm} / \mu \mathrm{g}$.

Serum bactericidal activity. SH5770 was grown in TSB alone or TSB containing subinhibitory concentrations of $\mathrm{CMZ}(0.195$ and 0.39 $\mu \mathrm{g} / \mathrm{ml})$ as described above. After washing twice with HBSS ++ the organisms were resuspended to $1 \times 10^{6} / \mathrm{ml}$ in $\mathrm{HBSS}++$, then mixed with an equal volume of serum, and incubated at $37^{\circ} \mathrm{C}$ tumbling end over end. At times $0,20,40,60$, and $120 \mathrm{~min}$, aliquots were diluted, plated in duplicate on LB agar, and grown $16-18 \mathrm{~h}$ at $37^{\circ} \mathrm{C}$. Colonies were counted with a bacterial colony counter (New Brunswick Scientific Co., Edison, NJ). Bacterial viability in experimental samples was compared to control tubes containing bacteria incubated in HIS.

Electron microscopy. Organisms were grown in CMZ or TSB, fixed with $2 \%$ glutaraldehyde, pelleted in a microcentrifuge, embedded in Epon 812 resin and thin sectioned on an ultramicrotome (Reichert Scientific, Vienna, Austria). Sections were then examined by transmission electron microscopy.

Bacterial hydrophobicity. Cell surface bacterial hydrophobicity was measured by the method of Rosenberg et al. (23). Briefly, $1 \mathrm{ml}$ of bacteria $\left(1 \times 10^{8} / \mathrm{ml}\right)$ was washed after growth to the midlogarithmic stage, resuspended to the same concentration in PUM's buffer, $\mathrm{pH} 7.1$ (22.2 $\mathrm{g} \mathrm{K}_{2} \mathrm{HPO}_{4}-3 \mathrm{H}_{2} \mathrm{O}, 7.26 \mathrm{~g} \mathrm{KH}_{2} \mathrm{PO}_{4}, 1.8 \mathrm{~g}$ urea, $0.2 \mathrm{~g} \mathrm{MgSO}_{4}-7 \mathrm{H}_{2} \mathrm{O}$ and distilled water to $1000 \mathrm{ml}$ ) then mixed with 100 or $200 \mu \mathrm{l}$ xylene. After preincubating at $30^{\circ} \mathrm{C}$ for 10 min the samples were rotated end over end for $120 \mathrm{~s}$. They were then allowed to settle at least $15 \mathrm{~min}$ or until the hydrocarbon phase had risen and completely separated from the aqueous phase. The aqueous phase was carefully removed and transferred to a 1-ml cuvette, and optical density measured at $400 \mathrm{~nm}$ on a spectrophotometer (Gilford Instruments Laboratories, Oberlin, $\mathrm{OH})$. Results are expressed as a percentage of the absorbance of aqueous suspensions to which no xylene had been added.

Bacterial lysis by detergents. To further evaluate effects of $\mathrm{CMZ}$ on cell wall hydrophobicity, susceptibility of SH5770 to detergent lysis was tested after growth in subMICs of CMZ. SH5770 grown with or without $\mathrm{CMZ}$ were incubated at $37^{\circ} \mathrm{C}$ for $10 \mathrm{~min}$ in increasing concentrations of Triton X-100 (TX100) or sodium deoxycholate (DOC) at or above their critical micellar concentrations (from $0.01 \%$ to $1 \%$ for TX100 and from $0.2 \%$ to $1 \%$ for DOC). Aliquots were diluted and spread evenly on LB agar. After growth for 16 to $18 \mathrm{~h}$ at $37^{\circ} \mathrm{C}$ colonies were counted and percent survival calculated.

Actinomycin D sensitivity. The ability of the hydrophobic antibiotic actinomycin D to enter SH5770 and inhibit RNA synthesis was tested using the method described by Lieve (24) with minor modifications. SH5770 grown in broth or in broth containing $0.39 \mu \mathrm{g} / \mathrm{ml} \mathrm{CMZ} \mathrm{were}$ washed and resuspended in $0.033 \mathrm{M}$ Tris- $\mathrm{Cl}$, $\mathrm{pH} 8$ at $5 \times 10^{9} / \mathrm{ml}$ con- centration. $8 \mathrm{ml}$ TSB were added to each sample and mixed well. Quantitative cultures on LB agar were performed to insure comparable numbers of viable CFU in each sample. Each sample was mixed with $\left[{ }^{3} \mathrm{H}\right]$ uracil $\left(5 \mu \mathrm{Ci} / 1 \times 10^{9}\right.$ bacteria, Dupont New England Nuclear, Boston, MA), then divided into two equal aliquots. Actinomycin D (10 $\mu \mathrm{g} / \mathrm{ml}$ final concentration, Sigma Chemical $\mathrm{Co}$.) was added to one aliquot of each sample which was then incubated at $25^{\circ} \mathrm{C}$. At times 0,5 , $10,30,40$, and $60 \mathrm{~min}$, three $100-\mu \mathrm{l}$ aliquots were added to ice cold $5 \%$ TCA containing 100 -fold unlabeled uracil at $0-4^{\circ} \mathrm{C}$. Precipitates were collected on filters (HA, $0.45 \mu \mathrm{m}$ pore size; Millipore Corp., Bedford, MA.), washed with water, dissolved in UltimaGold (Packard Co., Meriden, CT), and counted in a Packard Tri-Carb liquid scintillation counter (Downers Grove, IL).

Quantitative CMZ effects on $C 3$ and $C 9$ deposition. The effects of sub-MICs of CMZ on $\mathrm{C} 3$ and $\mathrm{C} 9$ deposition were tested. Tracer amounts of ${ }^{125} \mathrm{I}-\mathrm{C} 3$ or ${ }^{125} \mathrm{I}-\mathrm{C} 9$ were added to serum before it was mixed with an equal volume of bacteria $\left(2 \times 10^{9} / \mathrm{ml}\right)$ grown in sub-MICs of CMZ to bring final serum concentrations to desired levels, and bacterial concentrations to $1 \times 10^{9} / \mathrm{ml}$. The mixtures were incubated tumbling end over end at $37^{\circ} \mathrm{C}$ for $30 \mathrm{~min}$. Three separate $100-\mu$ l aliquots were then centrifuged through ice cold HBSS at $12,500 \mathrm{~g}$ for $5 \mathrm{~min}$. The supernatant was aspirated, the tip of the tube containing the bacterial pellet clipped, and pellet and supernatant counted separately in a Packard Cobra automatic multidetector gamma counter (Packard Instrument $\mathrm{Co}$.). Number of molecules of $\mathrm{C} 9$ or $\mathrm{C} 3$ bound to each organism was not calculated because CMZ-grown organisms were elongated and variable in length, and therefore presented inconsistent surface areas for complement deposition. Instead, results are expressed as the percentage of total radioactivity present in the reaction mixture that became bound to the bacteria. We then compared percent $\mathrm{C} 9$ that became bound to organisms to percent $\mathrm{C} 3$ bound to organisms.

Effects of $C M Z$ on the form of $C 3$ and $C 9$ deposited. The effect of sub-MICs of CMZ on the form of bound $\mathrm{C} 3$ was determined. Equal volumes of SH5770 $\left(2 \times 10^{9} / \mathrm{ml}\right)$ grown in sub-MICs of CMZ and $10 \%$ serum containing ${ }^{125} \mathrm{I}-\mathrm{C} 3$ were mixed. After $30 \mathrm{~min}$ incubation at $37^{\circ} \mathrm{C}$ with serum, the mixture (total volume $400 \mu \mathrm{l}$ ) was centrifuged at $12,500 \mathrm{~g}$ for $5 \mathrm{~min}$, washed in HBSS ++ , and the pellet solubilized by boiling in 2\% SDS for $8 \mathrm{~min}$. In some cases, one half of each C3-bacterial pellet was subsequently treated with methylamine (final concentration $\sim 26 \mathrm{mM}$ ) in carbonate buffer, $\mathrm{pH} 11$, at $37^{\circ} \mathrm{C}$ for $60 \mathrm{~min}$ to release $\mathrm{C} 3$ linked by ester bonds (25). Sodium dodecyl sulfate polyacrylamide gel $(7.5 \%$ gel) electrophoresis of solubilized samples was then performed and autoradiography done using dried gels.

The effect of sub-MICs of $\mathrm{CMZ}$ on the form of $\mathrm{C} 9$ bound also was ascertained. SH5770 $\left(200 \mu \mathrm{l}, 2 \times 10^{9} / \mathrm{ml}\right)$ grown in sub-MICs of CMZ were mixed with $200 \mu \mathrm{l} 5 \%$ serum containing ${ }^{125} \mathrm{I}-\mathrm{C} 9$ and incubated at $37^{\circ} \mathrm{C}$ for $30 \mathrm{~min}$. The bacteria were then washed with HBSS ++ and solubilized in $2 \%$ SDS. Solubilized samples were loaded onto a $2.5 \%$ to $20 \%$ polyacrylamide gradient gel and electrophoresed. After drying, gels were used to perform autoradiography.

Detection of poly C9 on bacteria by ELISA. SH5770 was grown and incubated in serum as above for evaluation of $\mathrm{C} 9$ bound to bacteria by electrophoresis and autoradiography. After washing, the organisms were adjusted to $2 \times 10^{8} / \mathrm{ml}$ in carbonate buffer, $\mathrm{pH} 9.55$, and $50 \mu \mathrm{l} \mathrm{(1}$ $\times 10^{7}$ organisms/well) used to coat 96 well polystyrene microtiter plates (Costar Corp., Cambridge, MA) overnight. The primary antibody was murine ascites monoclonal antibody directed against a neoantigen on poly-C9 (MAb pC9, gift of Dr. Ronald J. Falk, Chapel Hill, NC, see reference 26 for description) used at dilutions from 1:100 to 1:5,000 in HBSS ++ containing $5 \%$ goat serum. Secondary antibody (diluted $1: 250$ in $5 \%$ goat serum in HBSS ++ ) was horseradish peroxidase-conjugated goat anti-murine IgG (Miles Pharmaceuticals, West Haven, CT) that was developed with the substrate $o$-phenyldiamine (Bio-Rad Laboratories). Plates were read on a microtiter spectrophotometer (Emax Precision microplate reader; Molecular Devices, Menlo Park, CA). Negative controls were bacteria incubated in HBSS ++ or HIS then in primary and secondary antibodies. Other negative controls were bacteria incubated in ADS, then in $\mathrm{HBSS}++$ instead of primary 
antibody, followed by incubation with secondary antibody. For positive controls we preincubated SH5770 in rabbit antisera specific for SH5770 and known to support complement-mediated killing of SH5770. Antibody-sensitized SH5770 were incubated in serum, coated on plates, then incubated in primary and secondary antibodies.

Detection of poly $C 9$ on bacteria by immunofluorescence. Bacteria were grown in TSB alone or in TSB containing $0.39 \mu \mathrm{g} \mathrm{CMZ,} \mathrm{then}$ incubated in 5\% serum in HBSS ++. After washing in HBSS,$++ 10 \mu$ $\left(1 \times 10^{7} / \mathrm{ml}\right)$ from each sample were applied to wells of Teflon-coated slides (Cel-Line Associates, Inc., Newfield, NJ) and allowed to dry at room temperature. After fixing for $10 \mathrm{~min}$ in $96 \%$ methanol, $10 \mu \mathrm{l}$ MAb pC9 (diluted 1:10 in 5\% goat serum in HBSS ++ ) or $5 \%$ goat serum in HBSS++ was added to each well and the slides were incubated in a moist chamber for $120 \mathrm{~min}$ at $25^{\circ} \mathrm{C}$. After gently washing in $5 \%$ goat serum, $10 \mu \mathrm{l}$ affinity purified, FITC-derivatized, goat antimurine IgG (Zymed Laboratories, Inc., So. San Francisco, CA) diluted 1:40 in HBSS ++ containing 5\% goat serum was added to each well and incubated for $30 \mathrm{~min}$ at room temperature. After washing, the slides were examined by phase contrast and fluorescence microscopy (Nikon Microphot-FXA, Tokyo, Japan) and photographed. Negative controls were SH5770 incubated in HIS or in HBSS++ containing 5\% goat serum before exposure to primary and secondary antibodies. Positive controls were serum-sensitive Escherichia coli J5, an organism shown by others (8) to bind multimeric $\mathrm{C} 9$ when incubated in serum.

\section{Results}

CMZ effects on serum susceptibility. The ability of CMZ to influence survival of SH5770 in serum was evaluated. Organisms grown in the presence or absence of subinhibitory concentrations of CMZ were incubated in $50 \%$ serum for $20,40,60$, or 120 min. Fig. 1 shows kinetics of bacterial killing in ADS or HIS. SH5770 survived and multiplied $600 \%$ at $120 \mathrm{~min}$ in the presence of HIS whether grown in the presence or absence of $\mathrm{CMZ}$. Organisms grown in the absence of $\mathrm{CMZ}$ survived incubation in ADS and after a lag phase of 60 to $90 \mathrm{~min}$, recovered and multiplied. In contrast, growth in $\mathrm{CMZ}$ resulted in rapid killing of SH5770 by ADS in less than 20 min. Preincubation in specific antisera also resulted in rapid serum killing (data not shown).

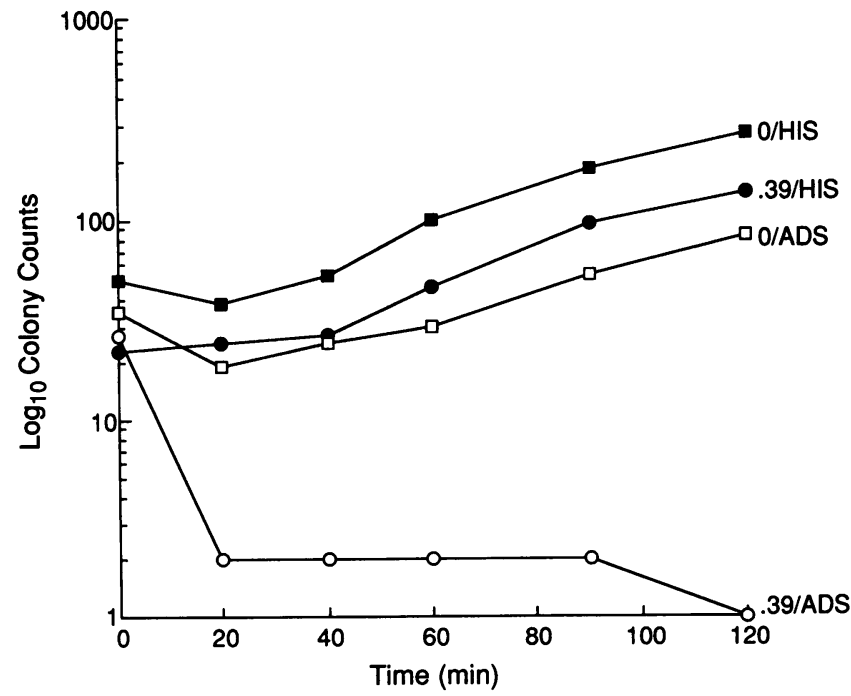

Figure 1. CMZ effects on serum susceptibility. SH5770 was grown in broth alone or in $0.39 \mu \mathrm{g} / \mathrm{ml} \mathrm{CMZ}$ then incubated at $37^{\circ} \mathrm{C}$ at a concentration of $5 \times 10^{5} / \mathrm{ml}$ in $50 \%$ ADS or HIS. Samples were cultured after $20,40,60$, and 120 min of serum incubation.

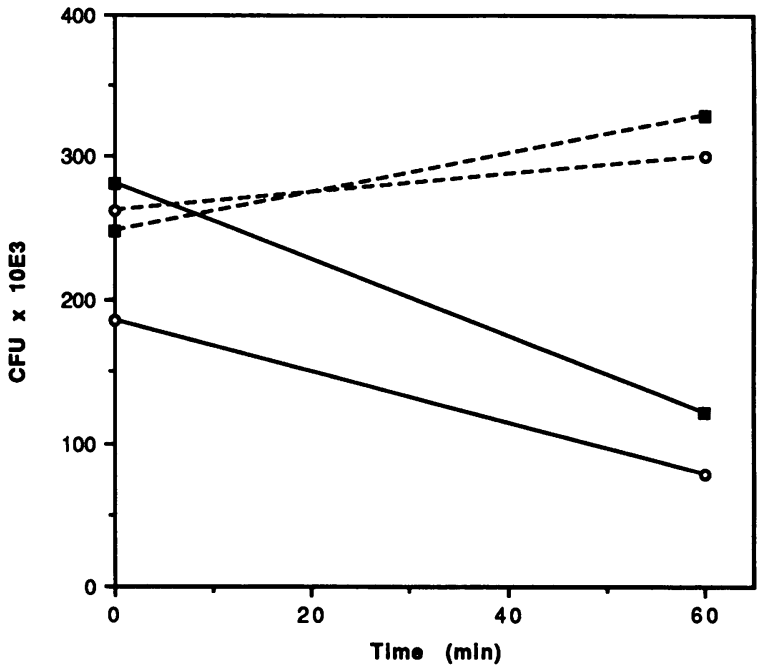

Figure 2. SH5770 was grown in broth alone or in $0.39 \mu \mathrm{g} / \mathrm{ml} \mathrm{CMZ}$ $(-0-, 0 ;-\infty-, 39 ;-\square-, 0 ; \longrightarrow-.39)$ then incubated at $37^{\circ} \mathrm{C}$ at a concentration of $5 \times 10^{5} / \mathrm{ml}$ in $25 \%$ serum adsorbed with CMZ-grown SH5770 (closed squares), ADS (open circles), or HIS (not shown). Samples were cultured after 0 and $60 \mathrm{~min}$ of serum incubation.

In order to eliminate the possibility that antibodies specific for antigens located deep within the bacterial outer membrane, but exposed upon growth in CMZ, were responsible for bacterial death, normal serum was adsorbed with CMZ-grown plus broth-grown SH5770. Results (Fig. 2) of bactericidal assays performed with that serum was similar to those observed with ADS. Less dramatic bactericidal activity was observed in these experiments compared to those shown in Fig. 1 because only one half the concentration of serum was added to samples shown in Fig. 2.

Quantitative effects of CMZ on C3 binding. We measured C3 binding to SH5770 to determine if the primary mechanism for serum bactericidal activity was increased $\mathrm{C} 3$ deposition. Organisms grown in one-quarter the $\operatorname{MIC}$ of $\mathrm{CMZ}(0.39 \mu \mathrm{g} / \mathrm{ml})$ consistently bound a greater percentage of ${ }^{125} \mathrm{I}-\mathrm{C} 3$ than brothgrown organisms at all serum concentrations tested (Fig. 3). Although growth in $0.195 \mu \mathrm{g} / \mathrm{ml} \mathrm{CMZ}$, one-eighth the MIC, did not affect $\mathrm{C} 3$ binding at low serum concentrations, $\mathrm{C} 3$ binding increased significantly with incubation in $10 \%$ serum (Fig. 3).

Qualitative effects on $C 3$ binding. Growth in CMZ may affect the form of $\mathrm{C} 3$ bound, as well as enhance $\mathrm{C} 3$ binding. The form of bound $\mathrm{C} 3$ dictates whether the $\mathrm{C} 5$ convertase will form, leading to assembly of the cytolytic C5b-9 complex. C3b but not iC $3 \mathrm{~b}$ participates in $\mathrm{C} 5$ convertase formation, whereas both $\mathrm{C} 3$ fragments are opsonic. In addition, the nature of the C3-acceptor bond may vary. C3 binds covalently to bacterial constituents via ester linkages, usually to carbohydrates, or via amide linkages, usually to proteins.

We investigated the form of $\mathrm{C} 3$ deposited and the nature of the C3-acceptor bond on SH5770 grown in the presence or absence of CMZ. C3-acceptor complexes $>200 \mathrm{kD}$ formed, seen barely entering the $7.5 \%$ gel in Fig. 4 in both the presence and absence of CMZ. As expected, nonactivated $\mathrm{C} 3$ migrated in the gel as the $120-\mathrm{kD} \alpha$ chain and the $75-\mathrm{kD} \beta$ chain (Fig. 4, lane $C 3$ ). Upon releasing ester-linked $\mathrm{C} 3$ by treatment with 


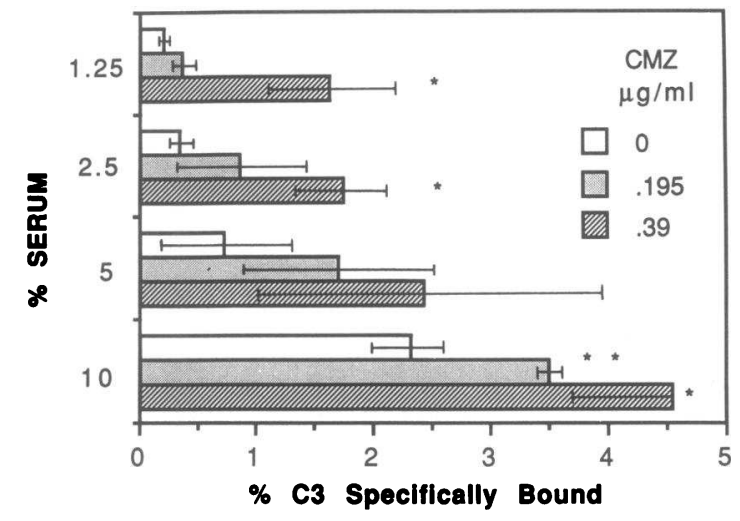

Figure 3. Specific binding of $\mathrm{C} 3$ to $\mathrm{SH} 5770$ grown in CMZ then incubated in serum. SH5770 was grown in $0,0.195$, or $0.39 \mu \mathrm{g} / \mathrm{ml}$ $\mathrm{CMZ}$, then $1 \times 10^{9}$ organisms $/ \mathrm{ml}$ were incubated at $37^{\circ} \mathrm{C}$ for $30 \mathrm{~min}$ in ADS to which tracer amounts of ${ }^{125} \mathrm{I}-\mathrm{C} 3$ had been added. Serum concentrations ranged from $1.25 \%$ to $10 \%$. Control tubes contained the same concentrations of HIS with ${ }^{125} \mathrm{I}-\mathrm{C} 3$. Percent $\mathrm{C} 3$ bound to bacteria in HIS was subtracted from $\mathrm{C} 3$ bound in ADS to calculate specific binding. Results are the means \pm SD of two separate experiments performed in triplicate. ${ }^{*} P<0.01 ;{ }^{* *} P<0.05$.

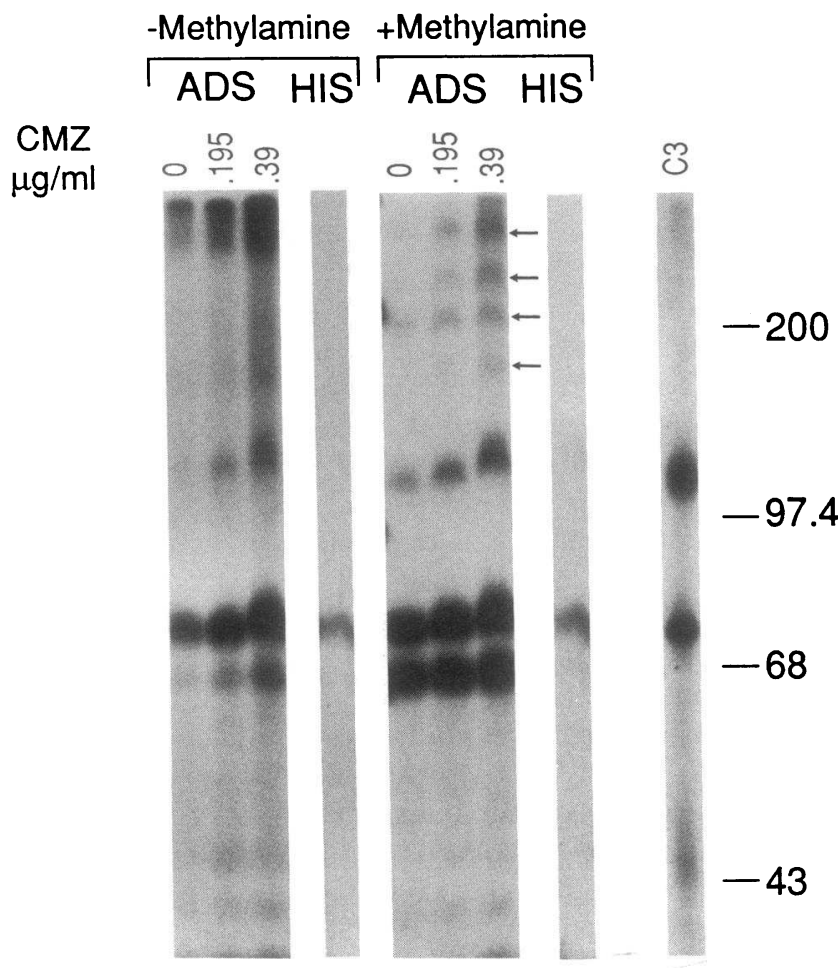

Figure 4. Form of $\mathrm{C} 3$ bound and nature of the $\mathrm{C} 3$-acceptor linkage. SH5770 was grown in CMZ as in Fig. 3, then as indicated in 5\% ADS or HIS containing trace amounts of ${ }^{125} \mathrm{I}-\mathrm{C} 3$. Seen here are autoradiograms of samples electrophoresed under reducing conditions on $7.5 \%$ polyacrylamide gels. Native, radiolabeled $\mathrm{C} 3$ is seen in the lane at the far right. Half of each sample was treated with methylamine (+methylamine) before electrophoresis. In the absence of methylamine (-methylamine) C3 migrates primarily as large molecular weight C3-bacterial constituent complexes, whether or not organisms were grown in CMZ. After methylamine treatment most of the $\mathrm{C} 3$ is released and migrates as the $68 \mathrm{kD} \mathrm{iC} 3 \mathrm{~b}$ band and the $110 \mathrm{kD} \mathrm{MW} \mathrm{C} 3 \mathrm{~b}$ band $(\sim 2.5: 1$ ratio). Four distinct large complexes (arrows) persist in each lane indicating that some of the $\mathrm{C} 3$ is linked via amide bonds. No $\mathrm{C} 3$ activation is observed in HIS. methylamine, $\mathrm{C} 3$ that had been bound to broth-grown as well as to CMZ-grown SH5770, migrated as $\mathrm{C} 3 \mathrm{~b}$ (110 $\mathrm{kD} \alpha^{\prime}$ chain) and $\mathrm{iC} 3 \mathrm{~b}\left(68 \mathrm{kD} \alpha_{1}^{\prime}\right.$ chain) along with the $75-\mathrm{kD} \beta$ chain. The ratio of $\mathrm{iC} 3 \mathrm{~b}$ to $\mathrm{C} 3 \mathrm{~b}$ was about 2.5 to 1 as assessed by densitometric scanning. In addition, four distinct C3-acceptor complexes of greater than $159 \mathrm{kD}$ resisted methylamine dissociation in all samples, although the bands were more intense in the lanes containing $\mathrm{CMZ}$-grown bacteria. Thus a portion of the bonds formed between $\mathrm{C} 3$ and bacterial constituents were amide linkages rather than oxy-ester linkages suggesting that this C3 was bound to bacterial proteins. Growth in CMZ did not affect the nature of the bond between $\mathrm{C} 3$ and the organism, nor the form of $\mathrm{C} 3$ bound, but may have altered the surface of the organism in such a way that more $\mathrm{C} 3$ binding sites were exposed to interact with $\mathrm{C} 3$.

Quantitative effects on $C 9$ binding. The effect of growth in CMZ on deposition of $\mathrm{C} 9$ was tested. Growth in sub-MICs of CMZ markedly enhanced C9 deposition on SH5770. The effect was dose related (Fig. 5) with over $12 \%$ of ${ }^{125} \mathrm{I}-\mathrm{C} 9$ bound to bacteria grown in $0.39 \mu \mathrm{g} / \mathrm{ml} \mathrm{CMZ}$, and $7 \%$ bound to bacteria grown in $0.195 \mu \mathrm{g} / \mathrm{ml} \mathrm{CMZ}$. In contrast, less than $2 \% \mathrm{C} 9$ was deposited on bacteria grown in broth alone, an amount no greater than control organisms incubated in HIS. Thus in the face of moderate increases in quantity of $\mathrm{C} 3$ bound, dramatic enhancement of $\mathrm{C} 9$ binding was seen with $\mathrm{CMZ}$.

Qualitative effects on $C 9$ binding. Earlier studies $(8,9,27)$ demonstrated that for serum to exert bactericidal activity, C9 must be stably inserted into the bacterial outer membrane in the form of multimeric C9. We demonstrated the presence of multimeric or poly-C9 on CMZ-grown SH5770 by three different experimental approaches. Poly-C9 is resistant to dissociation by 2 -mercaptoethanol reduction and boiling in 2\% SDS, the usual solubilization conditions for SDS-PAGE. When CMZ-grown SH5770 bearing ${ }^{125} \mathrm{I}-\mathrm{C} 9$ was analyzed, ${ }^{125} \mathrm{I}-\mathrm{C} 9 \mathrm{mi}-$ grated with and $M_{\mathrm{r}}$ of $190 \mathrm{kD}$ and greater (Fig. 6). Most ${ }^{125} \mathrm{I}-\mathrm{C} 9$ did not enter the gel, making it impossible to estimate the molecular weight, but certainly suggesting that it was in the form of polymeric C9 (Fig. 6). When broth-grown SH5770 were subjected to the same treatment, ${ }^{125} \mathrm{I}-\mathrm{C} 9$ migrated as monomeric

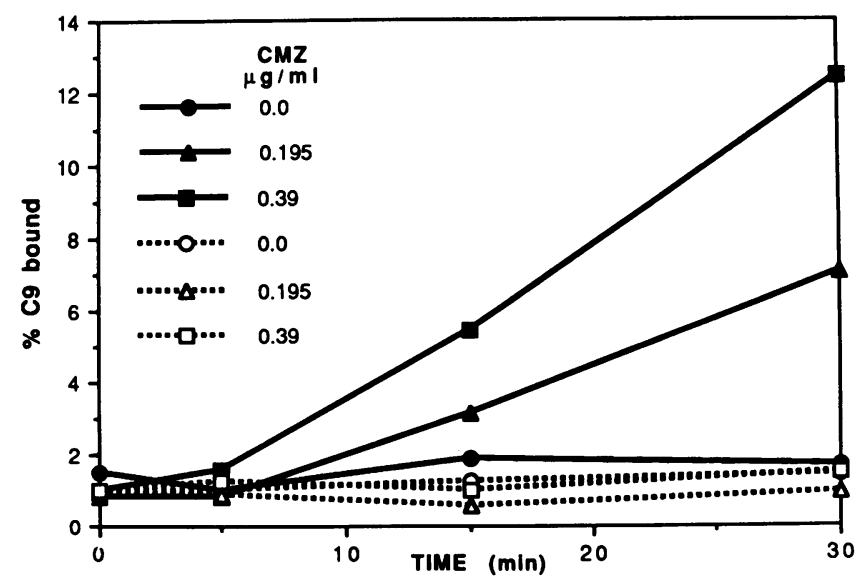

Figure 5. Specific binding of C9 to SH5770 grown in CMZ then incubated in serum. These experiments were performed exactly as those in Fig. 3 except tracer amounts of ${ }^{125} \mathrm{I}-\mathrm{C} 9$ were added to $2.5 \%$ serum and aliquots were counted at $0,5,15$, and $30 \mathrm{~min}$. Solid lines depict results for organisms incubated in ADS, dashed lines results for organisms in HIS. 


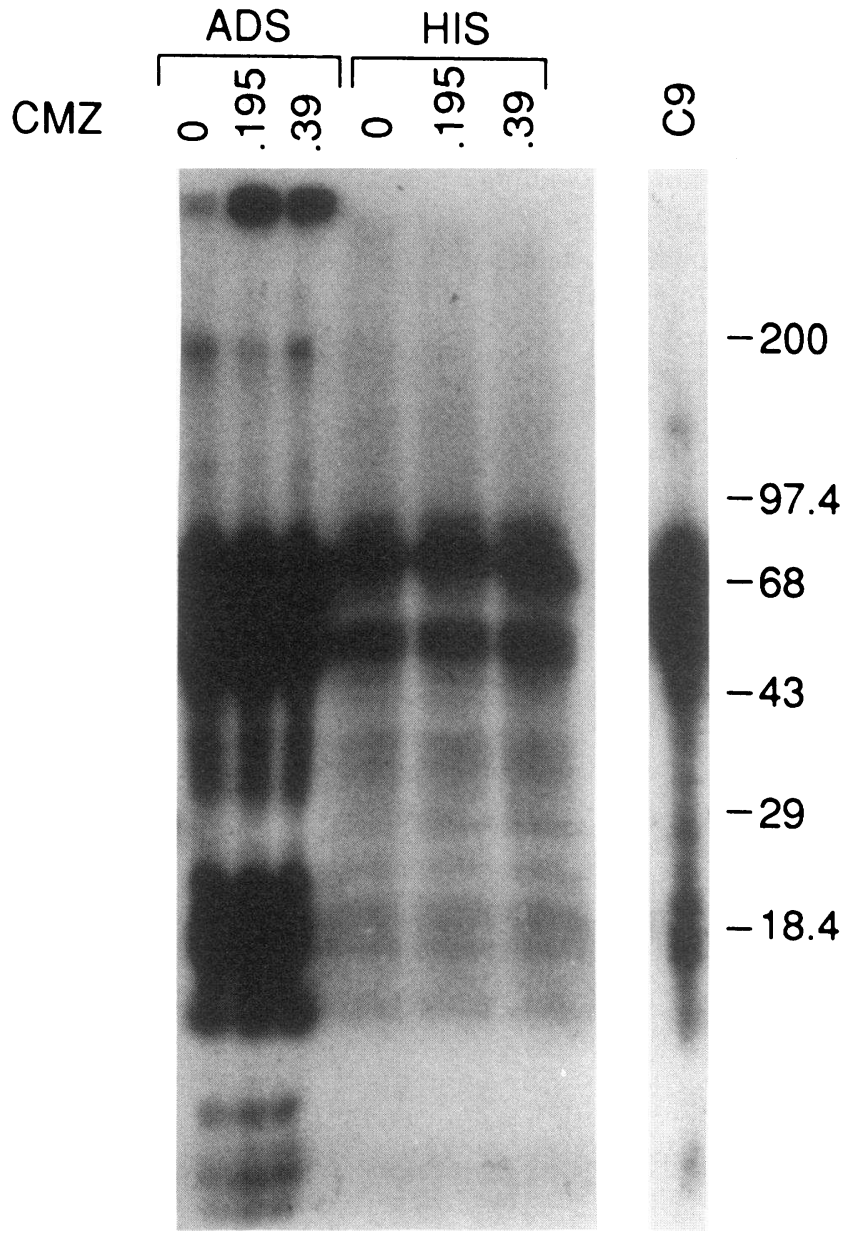

Figure 6. Complement membrane attack complexes form only on Salmonellae grown in sub-mics of cefmetazole. Form of $\mathrm{C} 9$ bound to SH5770 - SDS-PAGE/autoradiography. Samples treated exactly as described in the legend to Fig. 5 were washed, solubilized in 2\% SDS then electrophoresed under reducing conditions on a $2.5 \%$ to $20 \%$ polyacrylamide gradient gel. CMZ-grown bacteria incubated in ADS bound $\mathrm{C} 9$ in its polymeric form, seen at the tops of the lanes marked ADS. Little poly-C9 is seen in the lane containing SH5770 grown in broth alone (lane 0). Bacteria incubated in HIS had no multimeric C9 stably bound. Native C9 is seen at the far right, lane C9.

$\mathrm{C} 9(72 \mathrm{kD})$, and little if any poly-C9 was apparent at the tops of those lanes. Proteins of $68 \mathrm{kD}$ and smaller were seen in all samples incubated in ADS. These represent breakdown products of $\mathrm{C} 9$ of unknown biological significance.

We next used a monoclonal antibody (mAb pC9) directed against a neoantigen exposed only on poly-C9 to detect polyC9 by immunofluorescence on bacteria. CMZ-grown bacteria were strongly positive by immunofluorescence with $\mathrm{mAb}$ pC9 (Fig. 7, $D$ and $E$ ) whereas organisms grown in broth alone were negative (Fig. $7 F$ ). In addition, abnormal, extremely elongated, filamentous forms of fluorescent CMZ-grown SH5770 can be appreciated (Fig. $7 E$ ). Analogous organisms were observed in electron micrographs of samples grown in CMZ (see below). Broth-grown SH5770 are seen in Fig. 7, $C$ and $F$. Phase-contrast microscopy of samples are in Figure 7, $A-C$.

Using the same anti-poly $\mathrm{C} 9$ monoclonal antibody we performed enzyme-linked immunosorbant assays comparing broth-grown SH5770 to CMZ-grown organisms. CMZ-grown
SH5770 bound at least five times as much anti-poly-C9 as broth-grown microorganisms (Fig. 8) at low dilutions of $\mathrm{mAb}$ pC9. The signal was dose-related for CMZ-grown but not for broth-grown organisms. Thus by three different assays, poly $\mathrm{C} 9$ was detected on CMZ-grown but not broth-grown SH5770 following incubation in serum.

CMZ-induced cell wall changes in SH5770. $\beta$-lactam antibiotics are known to alter bacterial morphology $(4,28-31)$. As expected, electron microscopy demonstrated morphologic changes in CMZ-grown bacteria (Fig. $9 \mathrm{~B}$ ) compared to brothgrown organisms (Fig. $9 A$ ). Many of the bacteria were elongated (Fig. $9 \mathrm{~B}$ ) suggesting impaired septum formation (30). Most had cell wall disruptions and blebs formed in patchy distributions.

We also compared bacterial surface hydrophobicity in CMZ-grown and broth-grown SH5770 (Fig. 10). In comparison to broth-grown SH5770, a significant fraction of CMZgrown bacteria partitioned to the hydrocarbon phase of a diphasic mix of buffer and xylene, leaving fewer organisms in the aqueous phase and decreasing the aqueous optical density. Optical density of the hydrophilic phase of SH5770 grown in 0.39 $\mu \mathrm{g} / \mathrm{ml} \mathrm{CMZ}$ was only $25-30 \%$ the optical density of brothgrown bacteria. Thus the hydrophilicity of the bacterial cell walls was altered by growth in CMZ.

SH5770, inherently resistant to detergent lysis, loses resistance when its cell wall is disrupted and hydrophobic constituents deep within the cell wall are exposed. After incubation in TX100 or DOC at or above their critical micellar concentrations, SH5770 grown in CMZ were killed by all concentrations of detergent (Fig. 11). Broth-grown SH5770 remained resistant to all concentrations of TX100 (Fig. 11 A). Broth grown SH5770 was killed to a small degree by DOC, particularly at higher concentrations (Fig. 11, B). Thus CMZ altered the bacterial cell walls allowing detergents access to deep hydrophobic domains not accessible on intact cell walls. Upon detergent exposure, further cell wall disruption occurred with consequent lysis and cell death.

We performed additional experiments to test CMZ-induced changes in bacterial cell wall hydrophobicity. Actinomycin D, an inhibitor of RNA synthesis, does not affect smooth, wild-type gram negative bacteria unless there is disruption of the hydrophilic outer membrane, in particular disruption of lipopolysaccharide, permitting access to membrane lipid constituents (24). When CMZ-grown and broth-grown SH5770 were incubated in broth containing $\left[{ }^{3} \mathrm{H}\right]$ uracil, specific accumulation of $\left[{ }^{3} \mathrm{H}\right]$ uracil increased linearly for 30 to $40 \mathrm{~min}$ (Fig. 12). When samples contained actinomycin $D$, a 10-min lag in $\left[{ }^{3} \mathrm{H}\right]$ uracil incorporation was detected for both broth and CMZ-grown organisms. After 30 to 40 min of incubation, however, specific $\left[{ }^{3} \mathrm{H}\right]$ uracil incorporation was two- to threefold greater for broth than for CMZ-grown bacteria. Thus actinomycin D, itself hydrophobic, entered CMZ-grown organisms to a greater extent than broth-grown bacteria as reflected by greater inhibition of RNA synthesis.

\section{Discussion}

Our experiments clearly show that stable insertion of polymeric C9 into the bacterial cell wall is the mechanism of complement-mediated killing of SH5770 grown in subinhibitory concentrations of CMZ. We demonstrated marked enhance- 

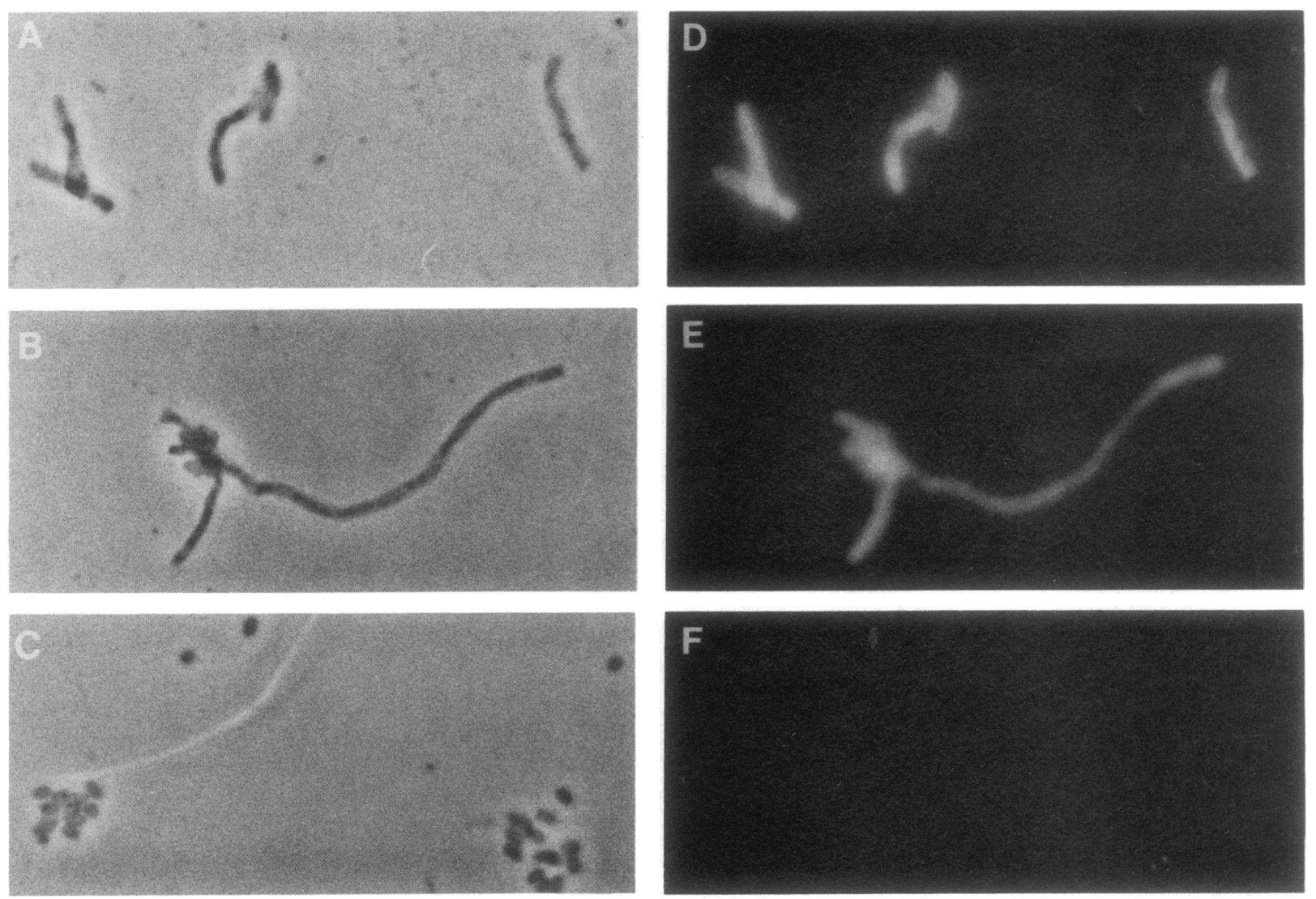

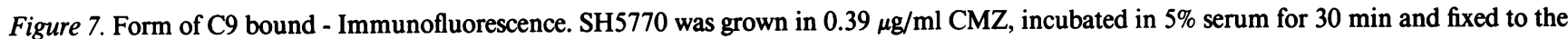
wells of Teflon-coated slides. Anti-poly $C 9$ murine monoclonal antibody (10 $\mu$ l) was added, followed by FITC-goat anti-murine IgG. $A, B, D$, and $E$ are CMZ-grown SH5770. $C$ and $F$ are broth grown. $A, B$, and $C$ are bacteria viewed by phase-contrast microscopy; $D, E$, and $F$ are immunofluorescence photomicrographs. All panels are photographed at $\times 100$.

ment of C9 deposition on CMZ-grown organisms. More importantly, however, a significant portion of bound $C 9$ was present as poly-C9, which is thought to be critical for bacterial killing (8-11). Thus we demonstrated at a molecular level the unique presence of polymeric $\mathrm{C} 9$ on genetically serum-resistant gram negative bacteria phenotypically converted to serum sensitivity by growth in subinhibitory concentrations of a $\beta$ lactam antibiotic, CMZ.

Darveau and Cunningham (32) recently reported that sublethal concentrations of cephalosporins increased complement-mediated serum bactericidal activity for Pseudomonas aeruginosa. They observed approximately twice as much C9 deposition on organisms in the presence of cephalosporins as in

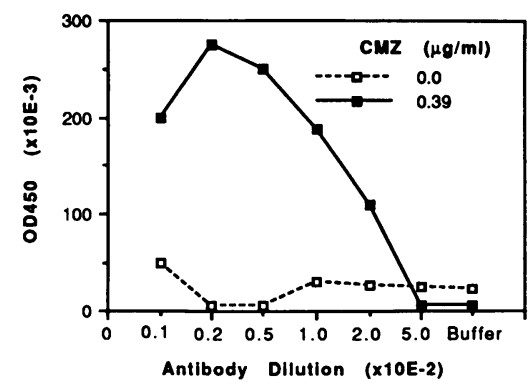

Figure 8. Form of $\mathrm{C} 9$ bound - ELISA. SH5770 was treated exactly as in Fig. 7 except samples were applied to wells of 96 well polystyrene microtiter plates. The primary antibody was the same monoclonal antibody used in Fig. 7 and was used at dilutions rang-

ing from 1:100 to $1: 5,000$. The secondary antibody was horseradish peroxidase-conjugated goat anti-murine IgG that was developed with $o$-phenyldiamine substrate. the absence of antibiotic. However, the amount of bound C9 may not be as important as the form of $\mathrm{C} 9$ bound $(7,8,33)$. Our studies have shown that in addition to increasing the amount of $C 9$ bound by more than sixfold, growth in subinhibitory concentrations of a $\beta$-lactam antibiotic allowed forma tion and insertion of lytic poly-C9 into the cell walls of gram negative bacteria.

The mechanism by which the membrane attack complex, and more specifically $\mathrm{C} 9$, kills bacteria is unknown. Activation of complement on the surface of susceptible gram negative bacteria results in formation and stable membrane insertion of the membrane attack complex, C5b-9 (reviewed in reference 34). Upon binding to C5b-8, C9 unfolds, probably exposing phospholipid binding sites that interact with bacterial cell wall phospholipids (35), most of which are located on the cytoplasmic membrane. One notion generally agreed upon is that $\mathrm{C} 9$ somehow affects the inner, cytoplasmic membrane of sensitive organisms, disrupting its permeability and disturbing its metabolism (36-41). Various mechanisms by which C9 may interact with the cytoplasmic membrane have been proposed. Nonetheless, C5b-9 complexes must initially insert into the outer membrane (reviewed in reference 42 ).

The major component of the bacterial outer membrane is lipopolysaccharide (35). A lipopolysaccharide molecule contains one copy of lipid A that is incorporated into the bacterial outer membrane lipid bilayer, a single core oligosaccharide, and from zero to more than 60 repeats of antigenic $O$-polysaccharide. $O$-polysaccharide confers hydrophilic characteristics 

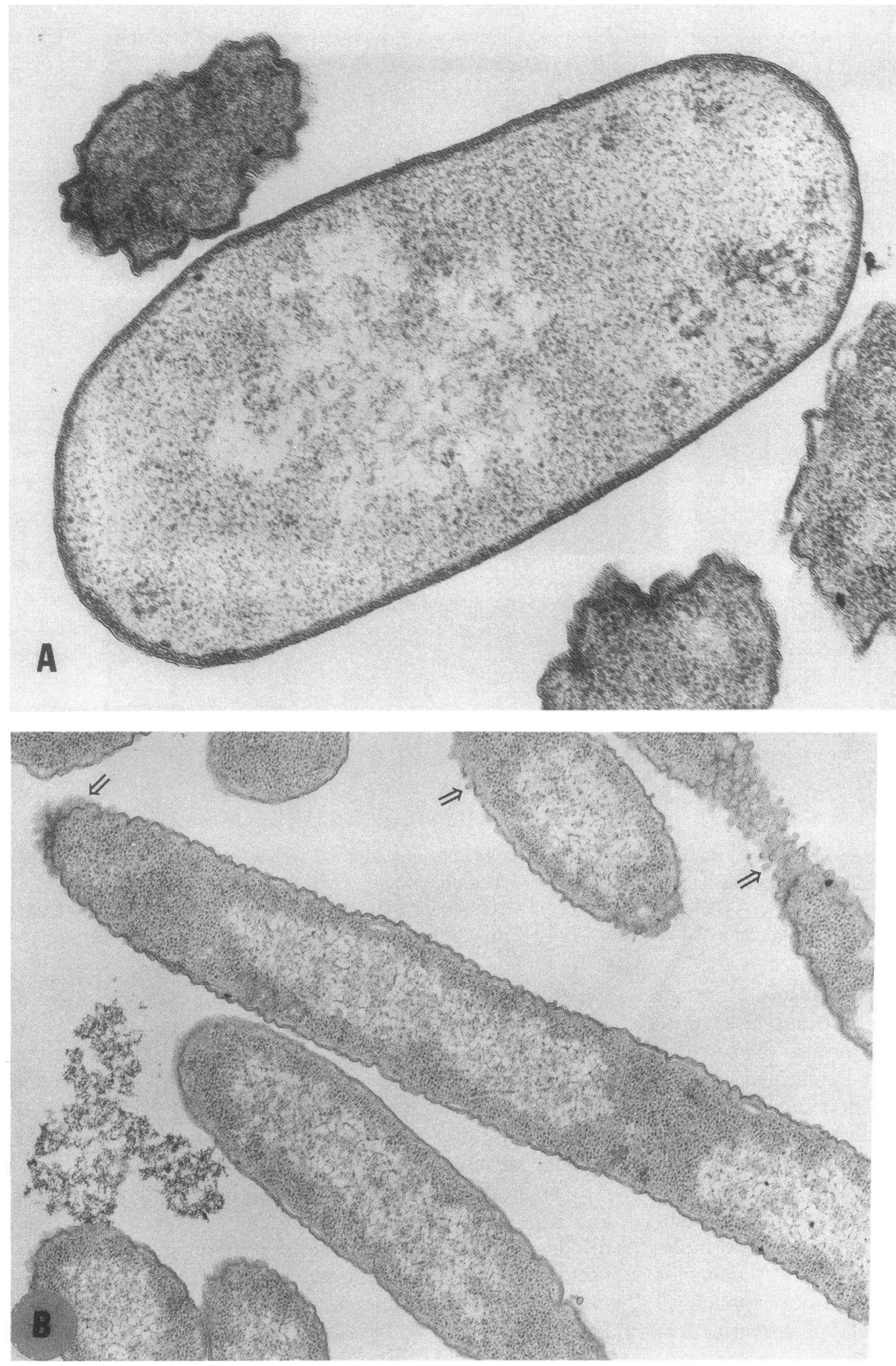

Figure 9. Transmission electron micrographs of SH5770 grown in TSB alone or in TSB containing CMZ. Shown is SH5770 grown in broth alone, $(A)$, or in $0.39 \mu \mathrm{g} / \mathrm{ml} \mathrm{CMZ \text {, }}$ $(B)$. Blebs are present (arrows) on CMZ-grown organisms in $(B)$.

to gram negative bacterial cell walls by forming a "canopy" over the more deeply located hydrophobic constituents. Grossman et al. (43) showed that serum sensitivity of a mutant of $S$. montevideo SH5770 was determined by both the size and distribution of lipopolysaccharide. A critical density of long $O$-antigen polysaccharide probably hinders access of C5b-9 to the outer membrane (reviewed in references 44 and 45 ). It is likely that subMICs of CMZ decrease the surface density of lipopolysaccharide allowing access of C5b-9 to the outer membrane.

Antibiotic-induced changes in cell wall morphology accompany conversion to serum sensitivity. $\beta$-lactam antibiotics block the transpeptidation reaction that attaches newly synthe- sized peptidoglycan to bacterial cell walls, producing a defective cell wall (46). Thus $\beta$-lactams specifically block murein synthesis, but other cell wall structures such as lipoproteins and lipopolysaccharides that may be anchored directly or indirectly in the peptidoglycan layer are affected as well.

Furthermore, other classes of antibiotics, with different specific mechanisms of action may cause similar cell wall changes that result in serum sensitivity (47-57, reviewed in 42). Regardless of the mechanism of action of antibiotics, subMIC-induced serum sensitivity is accompanied by very similar cell wall structural changes. The morphologic and serum sensitivity changes we observed in SH5770 grown in CMZ were consistent with 


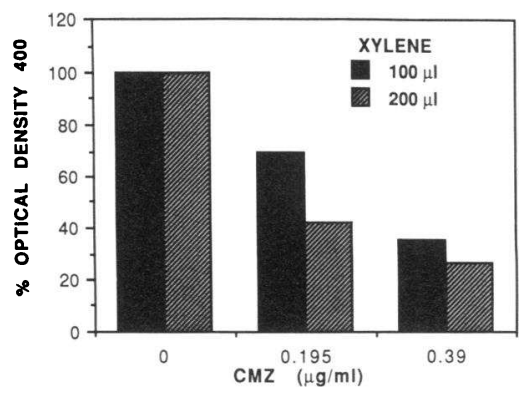

Figure 10. Bacterial hydrophobicity after growth in CMZ-phase separation. Organisms grown in broth alone or in 0.195 or $0.39 \mu \mathrm{g} / \mathrm{ml}$ $\mathrm{CMZ}$ suspended in buffer were mixed with xylene. Hydrocarbon and aqueous phases were allowed to separate and optical density at $400 \mathrm{~nm}$ of the aqueous phases determined. Optical density of brothgrown bacteria was considered $100 \%$. Results are representative of three separate experiments.
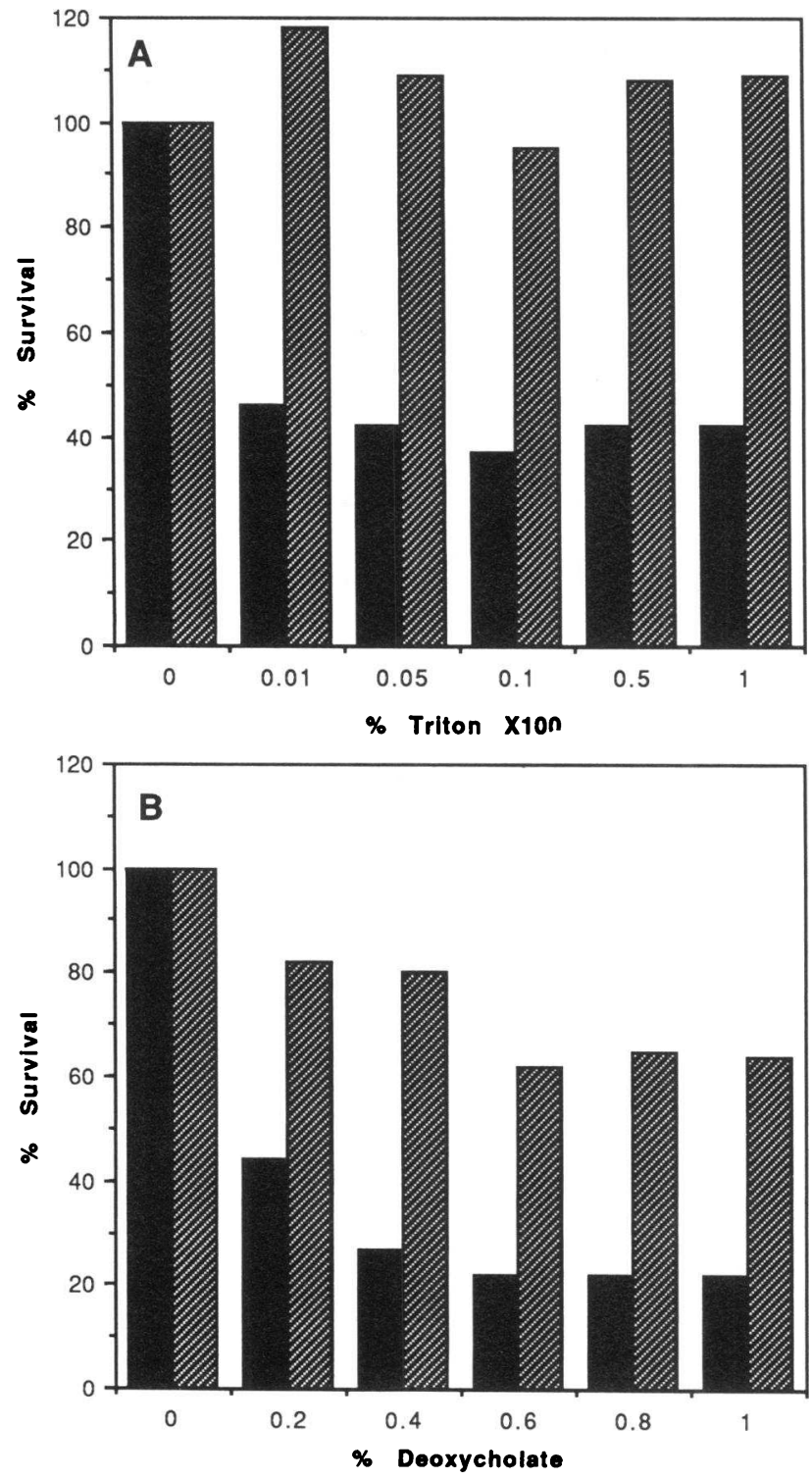

Figure 11. Bacterial hydrophobicity after growth in CMZ-susceptibility to detergent lysis. Bacteria were grown overnight in $\mathrm{CMZ}$ or broth, then incubated in increasing concentrations of Triton X100 $(A)$ or sodium deoxycholate $(B)$ for 10 min tumbling end over end. Diluted aliquots were spread evenly on LB agar, incubated $12-16 \mathrm{~h}$, then colonies counted. Solid bars represent bacteria grown in CMZ, bars with diagonal patterns represent bacteria grown in broth. The experiment shown for each detergent is representative of three experiments performed in triplicate.

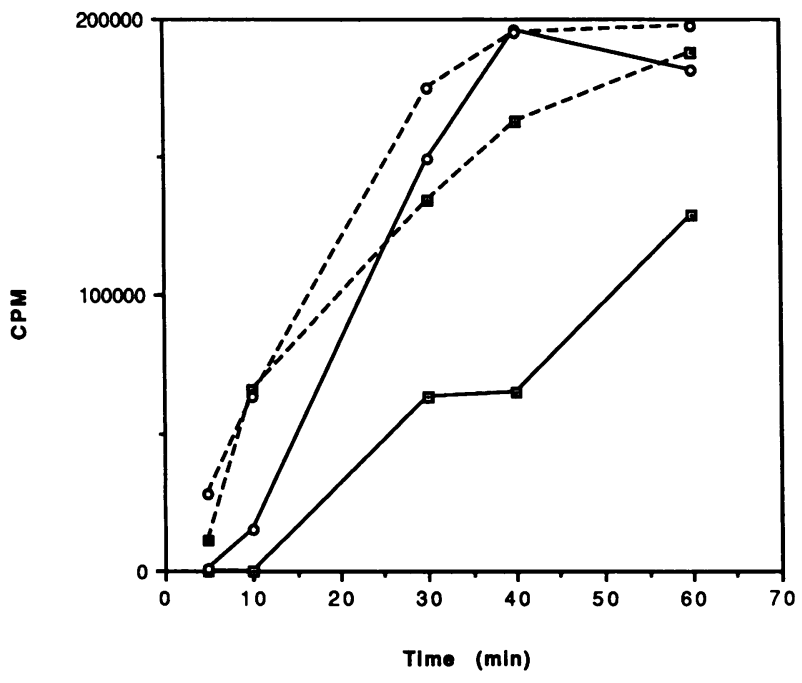

Figure 12. Bacterial hydrophobicity after growth in CMZ-actinomycin D inhibition of RNA synthesis. Bacterial suspensions were mixed with $\left[{ }^{3} \mathrm{H}\right]$ uracil, then half of each suspension mixed with actinomycin D. Samples were incubated at $25^{\circ} \mathrm{C}$, triplicate $100 \mu$ laliquots precipitated in ice cold trichloracetic acid, and precipitated radioactivity counted. In each case, broken lines represent organisms not exposed to actinomycin D. Squares represent organisms grown in CMZ, circles organisms grown in broth. The counts per minute of $\left[{ }^{3} \mathrm{H}\right]$ uracil at time 0 represent non-specific binding and were subtracted from each time point to reflect specific incorporation. The experiment shown is representative of two experiments, each done in triplicate.

previously reported findings $(2-6,28,47-53,57)$. In addition, we demonstrated that the bacterial morphologic changes were accompanied by increased hydrophobicity of the cell wall and we elucidated the mechanism of susceptibility to serum bactericidal activity.

C3 deposition also was enhanced although not to the extent of $\mathrm{C} 9$ deposition. The form of $\mathrm{C} 3$ bound and nature of the C3-acceptor linkages to CMZ-grown organisms were not changed by growth in subMICs of CMZ. There was no evidence by SDS-PAGE for the formation of new C3-acceptor complexes in CMZ-grown organisms. Finally, the ratio of $\mathrm{C} 3 \mathrm{~b}$ to $\mathrm{iC} 3 \mathrm{~b}$ was unaltered. However, many more molecules of $\mathrm{C} 9$ were able to insert and polymerize at the site of each bound $\mathrm{C} 3$ molecule, indicating that the major effect of $\mathrm{CMZ}$ was at the terminal pathway cascade.

Three lines of evidence suggested that $\mathrm{CMZ}$ increases the hydrophobicity of the outer membrane, bacterial separation to the hydrophobic organic phase when mixed with buffer and xylene, susceptibility to detergent lysis, and enhanced uptake of actinomycin D. It is likely that alterations in the bacterial cell wall we observed by electron microscopy, reflect loss of lipopolysaccharide and outer membrane proteins $(29,30)$ with subsequent movement of phospholipid to the outer leaflet. Exposure of phospholipid on the outer leaflet likely explains detergent susceptibility, actinomycin D access, and C5b-9 insertion.

Immunoelectron microscopy of CMZ-grown bacteria incubated in serum was performed to determine more precisely where poly-C9 is deposited relative to bacterial cell wall changes. Although more poly-C9 was present on CMZ-grown SH5770, no preferential binding at sites of obvious structural cell wall alterations could be appreciated (data not shown). 
These studies confirm and extend earlier experiments on the cooperative role of subMIC's of $\beta$-lactam antibiotics and complement by elucidating the mechanism for this effect. It has been speculated that this cooperative interaction may explain, at least in part, the postantibiotic effect of $\beta$-lactams.

\section{Acknowledgments}

We wish to thank Dr. Ronald J. Falk, University of North Carolina, Chapel Hill, NC, for generously supplying monoclonal antibodies directed against a poly-C9 neoantigen. We appreciate Dr. Keith A. Joiner, Yale University School of Medicine, New Haven, CT, for his critical review of the manuscript and for his unselfish advice. Dr. Vincent Quaglierello, also of Yale University School of Medicine, is acknowledged for his help with the electron microscopic studies.

This work was supported by a grant from The Upjohn Company, who supplied cefmetazole for these experiments as well.

\section{References}

1. Moellering, R. C., Jr. 1990. Principles of anti-infective therapy. In Principles and Practice of Infectious Diseases. G.,L. Mandell, R. G. Douglas, Jr., and J. E. Bennett, editors. Churchill Livingstone, New York. 206-218.

2. Feingold, D. S. 1969. The serum bactericidal reaction. IV. Phenotypic conversion of Escherichia coli from serum-resistance to serum-sensitivity by diphenylamine. J. Infect. Dis. 120:437-444.

3. Taylor, P. W., H. Gaunt, and F. M. Unger. 1981. Effect of subinhibitory concentrations of mecillinam on the serum susceptibility of Escherichia coli. Antimicrob. Agents Chemother. 19:786-788.

4. Taylor, P. W., H.-P. Kroll, and S. Tomlinson. 1982. Effect of subinhibitory concentrations of mecillinam on the expression of Escherichia coli surface components associated with serum resistance. Drugs Exptl. Clin. Res. VIII:625-631.

5. Alexander, W. J., C. G. Cobbs, and R. Curtiss III. 1980. Modification of bacterial serum susceptibility by rifampin. Infect. Immun. 28:923-926.

6. Sud, I. J., and D. S. Feingold. 1975. Detection of agents that alter the bacterial cell surface. Antimicrob. Agents Chemother. 8:34-37.

7. Joiner, K. A., K. A. Warren, E. J. Brown, J. Swanson, and M. M. Frank. 1983. Studies on the mechanism of bacterial resistance to complement-mediated killing. IV. C5b-9 forms high molecular weight complexes with bacterial outer membrane constituents on serum-resistant but not on serum-sensitive Neisseria gonorrhoeae. J. Immunol. 131:1443-1451.

8. Joiner, K. A., M. A. Schmetz, M. E. Sanders, T. G. Murray, C. H. Hammer, R. Dourmashkin, and M. M. Frank. 1985. Multimeric complement component C9 is necessary for killing of Escherichia coli $\mathrm{J} 5$ by terminal attack complex C5b-9. Proc. Natl. Acad. Sci. USA. 82:4808-4812.

9. Bhakdi, S., G. Kuller, M. Muhly, S. Fromm, G. Seibert, and J. Parrisius 1987. Formation of transmural complement pores in serum-sensitive Escherichia coli. Infect. Immun. 55:206-210.

10. Bloch, E. F., M. A. Schmetz, J. Foulds, C. H. Hammer, M. M. Frank, and K. A. Joiner. 1987. Multimeric C9 within C5b-9 is required for inner membrane damage to Escherichia coli J5 during complement killing. J. Immunol. 138:842848.

11. Joiner, K. A., A. B. Tartanian, C. H. Hammer, and J. E. Schweinle. 1989. Multimeric C9 within C5b-9 deposits in unique locations in the cell wall of Salmonella typhimurium. J. Immunol. 142:4450-4457.

12. Goldman, J. N., and K. F. Austen. 1974. Reaction mechanisms of nascent C567 (reactive lysis). II. Killing of a rough form of Escherichia coli by C567, C8, and C9. J. Infect. Dis. 129:444-450.

13. Joiner, K. A., R. Scales, K. A. Warren, M. M. Frank, and P. A. Rice. 1985. Mechanism of action of blocking immunoglobin $\mathrm{G}$ for Neisseria gonorrhoeae. J. Clin. Invest. 76:1765-1772.

14. Valtonen, V. V. 1970. Mouse virulence of Salmonella strains: the effect of different smooth-type O side-chains. J. Gen. Microbiol. 64:255-268.

15. Liang-Takasaki, C.-J., N. Grossman, and L. Leive. 1983. Salmonellae activate complement differentially via the alternative pathway depending on the structure of their lipopolysaccharide O-antigen. J. Immunol. 130:1867-1870.

16. Liang-Takasaki, C.-J., P. H. Makela, and L. Leive. 1982. Phagocytosis of bacteria by macrophages: changing the carbohydrate of lipopolysaccharide alters interaction with complement and macrophages. J. Immunol. 128:1229-1235.

17. Schweinle, J. E., R. A. B. Ezekowitz, A. J. Tenner, M. Kuhlman, and K. A. Joiner. 1989. Human mannose-binding protein activates the alternative comple- ment pathway and enhances serum bactericidal activity on a mannose-rich isolate of Salmonella. J. Clin. Invest. 84:1821-1829.

18. Jones, R. N. 1989. Review of the in vitro spectrum and characteristics of cefmetazole (CS-1170). Antimicrob. Agents Chemother. 23(D):1-12.

19. Sugawara, S., M. Tajma, I. Igarashi, S. Ohta, and Y. Utsui. 1976. 16th Interscience Conference on Antimicrobial Agents and Chemotherapy, 231. (Abstr.)

20. Jones, R. N. 1989. Cefmetazole (CS-1170), a "new" cephamycin with a decade of clinical experience. Diagn. Microbiol. Infect. Dis. 12:367-379.

21. Watanabe, Y., S. Tawarea, Y. Mine, H. Kikuchi, S. Goto, and S. Kuhara. 1986. Synergism of cephalosporins at subinhibitory concentrations and polymorphonuclear leukocytes on phagocytic killing of Escherichia coli and its mode of action. J. Antibiot (Tokyo). 39:294-303.

22. Hammer, C. H., G. H. Wirtz, L. Renfer, H. D. Gresham, and B. F. Tack. 1981. Large scale isolation of functionally active components of the human complement system. J. Biol. Chem. 256:3995-4006.

23. Rosenberg, J., D. Gutnick, and E. Rosenberg. 1980. Adherence of bacteria to hydrocarbons: a simple method for measuring cell-surface hydrophobicity. FEMS (Fed. Eur. Microbiol. Soc.) Microbiol. Lett. 9:29-33.

24. Lieve, L. 1965. Actinomycin sensitivity in Escherichia coli produced by EDTA. Biochem. Biophys. Res. Commun. 18:13-17.

25. Law, S.-K. A., and R. P. Levine. 1977. Interaction between the third complement protein and cell surface macromolecules. Proc. Natl. Acad. Sci. USA. 77:1116-1119.

26. Dalmasso, A. P., B. A. Benson, and R. J. Falk. 1984. Complement channels in membranes: inhibition with a monoclonal antibody to a neoantigen of polymerized C9. Biochem. Biophys. Res. Commun. 125:1013-1019.

27. MacKay, S. L. D., and J. R. Dankert. 1990. Bacterial killing and inhibition of inner membrane activity by $\mathrm{C} 5 \mathrm{~b}-9$ complexes as a function of the sequential addition of C9 to C5b-8 sites. J. Immunol. 145:3367-3371.

28. Gardner, A. D. 1940. Morphological effects of penicillin on bacteria. Nature (Lond). 148:837-838.

29. Horne, D., R. Hakenbeck, and A. Tomasz. 1977. Secretion of lipids induced by inhibition of peptidoglycan synthesis in Streptococci. J. Bacteriol. 132:704-717.

30. Goodell, E. W., M. Fazio, and A. Tomaz. 1978. Effect of benzylpenicillin on the syntheses and structure of the cell envelope of Neisseria gonorrhoeae. Antimicrob. Agents Chemother. 13:514-526.

31. Greenwood, D., and F. O'Grady. 1973. Comparison of the responses of Escherichia coli and Proteus mirabilis to seven $\beta$-lactam antibiotics. J. Infect. Dis. 128:211-222.

32. Darveau, R. P., and M. D. Cunningham. 1990. Influence of subinhibitory concentrations of cephalosporins on the serum sensitivity of Pseudomonas aeruginosa. J. Infect. Dis. 162:914-921.

33. Joiner, K. A., R. C. Goldman, C. H. Hammer, L. Leive, and M. M. Frank 1983. Studies of the mechanism of bacterial resistance to complement-mediated killing. V. $\operatorname{IgG}$ and $\mathrm{F}\left(\mathrm{ab}^{\prime}\right)_{2}$ mediate killing of $E$. coli $0111 \mathrm{~B} 4$ by the alternative complement pathway without increasing C5b-9 deposition. J. Immunol. 131:2563-2569.

34. Taylor, P. W., and H.-P. Kroll. 1985. Effect of lethal doses of complement on the functional integrity of target enterobacteria. Curr. Top. Microbiol. Immunol. 121:135-158.

35. Cronan, J. E. 1979. Phospholipid synthesis and assembly. In Bacterial Outer Membranes, Biogenesis and Functions. M. Inouye, editor. New York, John Wiley \& Sons. 35-65.

36. Esser, A. F., W. P. Kolb, E. R. Podack, and H. J. Muller-Eberhard. 1979. Molecular reorganization of lipid bilayers by complement: a possible mechanism for membranolysis. Proc. Natl. Acad. Sci. USA. 76:1410-1414.

37. Kroll, H.-P., S. Bhakdi, and P. W. Taylor. 1983. Membrane changes induced by exposure of Escherichia coli to human serum. Infect. Immun. 42:1055-1066.

38. Dankert, J. R., and A. F. Esser. 1986. Complement-mediated killing of Escherichia coli: Dissipation of membrane potential by a C9-derived peptide. Biochemistry 25:1094-1100.

39. Dankert, J. R., and A. F. Esser. 1987. Bacterial killing by complement. C9-mediated killing in the absence of C5b-8. Biochem. J. 244:393-399.

40. Der Meer, B. W., R. D. Fugate, and P. J. Sims. 1989. Complement proteins C5b-9 induce transbilayer migration of membrane phospholipids. Biophys. J. 56:935-946.

41. Goldman, R. C., and M. F. Miller. 1989. Complement attack of altered outer membrane areas synthesized after inhibition of the 3-deoxy-D-manno-octulosonate pathway leads to cell death. J. Immunol. 142:185-194.

42. Hancock, R. E. W. 1984. Alterations in outer membrane permeability. Annu. Rev. Microbiol. 38:237-264.

43. Grossman, N., M. A. Schmetz, J. Foulds, E. N. Klima, V. Jimenez, L. L. Lieve and K. A. Joiner. 1987. Lipopolysaccharide size and distribution determine serum resistance in Salmonella montevideo. J. Bacteriol. 169:856-863.

44. Taylor, P. W. 1983. Bactericidal and bacteriolytic activity of serum against gram-negative bacteria. Microbiol. Rev. 47:46-83. 
45. Joiner, K. A. 1988. Complement evasion by bacteria and parasites. Annu. Rev. Microbiol. 42:201-230.

46. Mirelman, D., R. Bracha, and N. Sharon. 1972. Role of the penicillin-sensitive transpeptidation reaction in attachment of newly synthesized peptidoglycan to cell walls of Micrococcus leuteus. Proc. Nat. Acad. Sci. USA. 69:33553359.

47. Feingold, D. S. 1969. The serum bactericidal reaction. IV. Phenotypic conversion of Escherichia coli from serum-resistance to serum-sensitivity by diphenylamine. J. Infect. Dis. 129:437-444.

48. Vaara, M., and T. Vaara. 1983. Sensitization of gram-negative bacteria to antibiotics and complement by a nontoxic oligopeptide. Nature (Lond.) 303:526-528.

49. Vaara, M., P. Viljanen, T. Vaara, and P. H. Makela. 1984. An outer membrane-disorganizing peptide PMBN sensitizes $E$. coli strains to serum bactericidal action. J. Immunol. 132:2582-9.

50. Vaara, M., and T. Vaara. 1983. Polycations as outer membrane-disorganizing agents. Antimicrob. Agents Chemother. 24:114-122.
51. Newton, B. A. 1956. The properties and mode of action of polymixins Bacteriol. Rev. 29:14-27.

52. Koike, M., K. lida, and T. Matwuo. 1969. Electron microscopic studies on mode of action of polymyxin. J. Bacteriol. 97:448-452.

53. Lopes, J., and W. E. Inniss. 1969. Electron microscopy of effect of polymyxin on Escherichia coli lipopolysaccharide. J. Bacteriol. 100:1128-1130.

54. Rifkind, K. 1967. Studies on the interaction between endotoxin and polymyxin. Br. J. Infect. Dis. 117:433-438.

55. Rifkind, D., and J. D. Palmer. 1966. Neutralization of endotoxin toxicity in chick embryos by antibiotics. J. Bacteriol. 92:815-819.

56. Leitman, P. S. 1990. Aminoglycosides and spectinomycin: aminocyclitols. In Principles and Practice of Infectious Diseases. G. L. Mandell, R. G. Douglas, Jr., and J. E. Bennett, editors. New York, Churchill Livingstone. 269284.

57. Hancock, R. E. W., V. J. Raffle, and T. I. Nicas. 1981. Involvement of the outer membrane in gentamicin and streptomycin uptake and killing in Pseudomonas aeruginosa. Antimicrob. Agents Chemother. 19:777-785. 